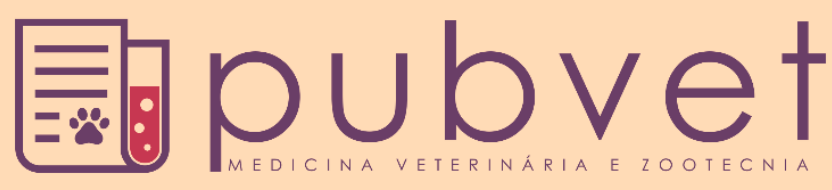

https://doi.org/10.31533/pubvet.v15n08a894.1-8

\title{
Hypercalcemia in bitches with malignant mammary neoplasms
}

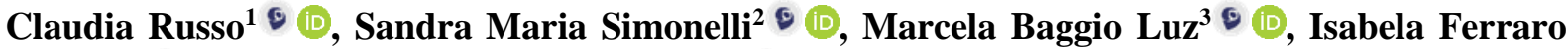

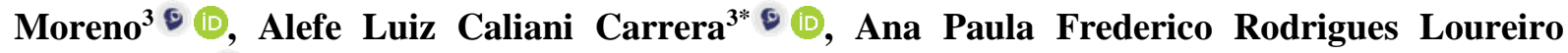 \\ Bracarense $^{40}$ (D)
}

${ }^{I}$ Postgraduate Program in Animal Science, Veterinary Medicine Department. Londrina State University, Londrina, Parana, Brazil. ${ }^{2}$ Center for Agricultural Sciences, Department of Zootechnics, Londrina State University, Londrina, Parana, Brazil.

${ }^{3}$ Veterinary Medicine Department Cesumar University, Maringa, Parana, Brazil.

${ }^{4}$ Department of Preventive Veterinary Medicine, Londrina State University, Londrina, Parana, Brazil.

*Corresponding author, E-mail: alefe_luiz@hotmail.com

\begin{abstract}
Malignant hypercalcemia is a paraneoplastic syndrome. It has been detected in several types of malignant tumours in dogs, such as lymphomas, and also in mammary neoplasms, without the exact determination of the mechanisms involved in its occurrence as well as its incidence. In this study, 100 bitches with mammary malignant neoplasia, diagnosed by histopathological analysis, were submitted to clinical evaluation for disease staging, haematological evaluation, serum biochemistry, including renal function tests, hepatic and total calcium serum levels and ionized fraction. These parameters were analyzed at the time of the initial attendance and 30 days after the treatment. The most frequent histological pattern was carcinoma in mixed tumors (26\%). In 52\% of the diseased dogs, hypercalcemia was observed by means of ionized calcium dosing, which was not verified by means of total calcium dosing, where only $4 \%$ presented hypercalcemia. No correlation was found between hypercalcemia and the histological pattern of the neoplasms. However, the correlation was verified between hypercalcemia and more advanced stages of the disease, mainly from stage III, suggesting that the detection of hypercalcemia may be correlated with worse prognosis, showing the importance of the research concerning the presence of paraneoplastic syndromes in bitches with mammary neoplasms.
\end{abstract}

Keywords: Canine, ionized calcium, mammary neoplasms, paraneoplastic syndromes

\section{Hipercalcemia em cadelas portadoras de neoplasia mamária malignas}

Resumo. A hipercalcemia maligna, ou seja, aquela que ocorre como um processo mórbido conhecido por síndrome paraneoplásica, tem sido detectada em diversos tipos de tumores malignos na espécie canina, como os linfomas, neoplasias dos sacos anais e também nas neoplasias mamárias, nestas ultimas porém, sem a determinação exata de quais os mecanismos envolvidos em sua ocorrência bem como sua incidência. Neste estudo, 100 cadelas com câncer de mama, com diagnóstico histopatológico confirmado, foram submetidas a avaliação clínica para estadiamento da doença, avaliação hematológica, bioqúimica sérica, incluindo testes de função renal, hepática e níveis séricos de cálcio total e a fração ionizada, no momento de sua abordagem e 30 dias após realização de tratamento. O carcinoma em tumor misto foi o padrão histológico mais frequente (26\%). Em 52 (52\%) das cadelas doentes, foi constatada a hipercalcemia, por meio da dosagem de cálcio ionizado, o que não foi verificado quando a análise foi feita por meio de dosagem de cálcio total, onde apenas 4 (4\%) apresentaram hipercalcemia. Não foi verificada associação entre hipercalcemia e o padrão histológico das neoplasias, porém a correlação foi verificada entre hipercalcemia e estadiamentos mais avançados da doença, principalmente à partir do 
estágio III, sugerindo que a detecção de hipercalcemia possa estar correlacionada ao pior prognóstico, demonstrando a importância da pesquisa referente a presença de síndromes paraneoplásicas em cadelas com neoplasias mamárias.

Palavras-chave: Cálcio ionizado, caninos, síndromes paraneoplásicas, tumores de mama

\section{Introduction}

Mammary cancer in dog corresponds to approximately $52 \%$ of all canine tumours, being considered an alteration of great interest in veterinary oncology, because to its high incidence, they represent a wide topic of research on diagnosis methods, treatments and prognostic factors (Cassali et al., 2014; Queiroga \& Lopes, 2002). It may be related to a series of systemic changes, called paraneoplastic syndromes. Anemia, leukocytosis, coagulopathies, thrombocytopenia and disseminated intravascular coagulation have been more frequently identified and studied (Bergman, 2007).

Hypercalcemia in the canine species has been reported in several types of tumours, including mammary neoplasms, however, its frequency has been more frequently associated with lymphomas and neoplasms of the anal sacs (Bergman, 2013; Withrow et al., 2020). In women, hypercalcemia associated with malignant mammary cancer was related to the production of a polypeptide called parathyroid hormone protein (PTHrP) and other cytokines by neoplastic cells. These factors, in addition to promoting bone calcium resorption, also influence the release of growth factors present in the bone matrix, stimulation the growth of malignant cells (Khosla, 2001). Although hypercalcemia is frequently cited in articles on mammary cancer in dogs, its mechanism still not well understood.

These data indicate that mammary cancer can also be the cause of other disorders unrelated to the local presence of the tumour or its metastases. Considering that the data available in the literature on the occurrence of hypercalcemia in female dogs with mammary cancer are scarce, the present study aimed to verify the frequency of hypercalcemia in female dogs with malignant mammary tumour, by measuring serum calcium total values and ionized calcium, as well as investigating possible correlations between hypercalcemia, clinical staging and histological classifications of tumours, biochemical and haematological changes.

\section{Material and methods}

In order to carry out this study, 119 female dogs with mammary cancer were seen from October 2012 to December 2013, at the Veterinary Hospital of Cesumar University - Unicesumar, located in the Maringá city, Paraná, after approval by the bioethics committee in institutional animal experimentation (COBAC/CESUMAR 014/2012).

The animals included in the study, after authorization from the guardians, underwent clinical evaluation, clinical staging of the disease, blood collection for hematological evaluation, serum biochemistry and total calcium (Cat) and ionized fraction (iCa). To determine hematological parameters, the routine techniques described by Jain \& Jain (1993) were used. The blood samples were placed in a flask containing the anticoagulant ethylenediaminetetraacetic acid ( $3 \mathrm{ml}$ of blood). The total erythrocyte and leukocyte count and the determination of the hemoglobin concentration were performed with the aid of the automatic cell counter (Celm CC 530/DA 500 ${ }^{\circledR}$, Brazil). The globular volume (GV) was determined by the microhematocrit method and the plasma protein concentrations by the refractometer method. The mean corpuscular volume (MCV) and the mean corpuscular hemoglobin concentration (MCHC) were calculated following the formulas described by Wintrobe (1974). For biochemical tests, blood samples $(10 \mathrm{ml})$ were collected from each animal by puncture of the jugular vein. The samples were placed in tubes without anticoagulant to determine the biochemical concentrations of ALT, FA, urea and creatinine, following the protocol established by the manufacturer (specific commercial kit Gold Analisa ${ }^{\circledR}$ ). To determine urea and ALT, kinetic-UV method was used and for the determination of creatinine and FA the kinetic-colorimetric method. The results were read and obtained using a Bioplus$200^{\circledR}$ photometric analyzer, Brazil, Serum measurements of total calcium and ionized fraction were performed at São Camilo Laboratory, in the city of Maringá, Paraná. The determination of the ionized calcium concentration was made using the selective electrode method with automatic correction for $\mathrm{pH}$

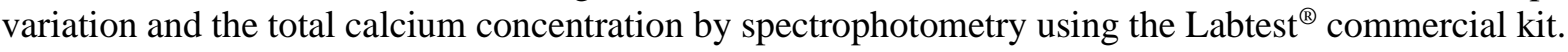


For clinical staging, imaging exams for distant metastasis using abdominal ultrasound and chest radiographic evaluation were also include according to Cassali et al. (2014). After initial clinical evaluation and obtaining the results of clinical analyzes, the animals were submitted to surgical treatment, as indicated for each case. In cases where there was a suspicion of a diagnosis of mammary cancer without indication of surgical treatment, such as inflammatory carcinomas, only incisional biopsy was performed. After performing the surgical procedures, the fragments of neoplastic tissues and inguinal and auxiliary lymph nodes were sent for histopathological analysis, thus allowing to obtain all the information necessary for staging and confirming the diagnosis of malignant cancer. Thirty days after the surgeries or biopsies were performed, the dogs were again submitted to blood sampling to repeat the same laboratory evaluations performed initially (post-treatment group). Four animals were not evaluated during this period because they died or were euthanized due to complications. The female dogs that had a clinical and histopathological diagnosis of primary or secondary inflammatory carcinoma were treated in a palliative manner, with a multimodal analgesia protocol, non-steroidal antiinflammatory drugs, chemotherapy and supportive therapy.

The data were tested for normality by the Shapiro Wilk test (Shapiro \& Wilk, 1965) and for homogeneity of variances by the Bartlett test (Bartlett, 1950). Normal reference and pretreatment values were compared by the t-test for independent samples and the pretreatment and post-treatment groups were compared by the paired t-test. To verify associations between serum calcium levels and changes in hematological and biochemical tests and the effect of tumor staging, analysis of variance and regression analysis were performed.

\section{Results and discussion}

Despite the fact that the biologically active fraction of calcium is the ionized fraction, it is usually done, at least initially, to total calcium dosage, using formulas to correct and obtain the ionized calcium values, adjusting the total calcium concentration to the protein concentrations and albumin (Bonczynski, 2007). However, some studies have already shown that, since the formulas used to correct total calcium values were stablished without confirmation of laboratory values of ionized calcium, considerable disagreement can occur (Schenck \& Chew, 2006; Schenck \& Chew, 2005; Scheneck, 2010). In a study in which 1633 canine serum samples were evaluated, when the total calcium concentration was used to predict the ionized fraction, the disagreement reached 27\% (Schenck \& Chew, 2005). According to Barber (2001), only the direct determination of the ionized calcium concentration should be considered, and not its prediction through correction formulas.

In this study, animals with mammary cancer showed serum total calcium values within normal parameters both before and after treatment. Regarding ionized calcium, levels above normal parameters were observed before treatment. However, after treatment, the values decreased to normal parameters. The average values of total and ionized calcium measured in animals before and after treatment are shown in Table 1.

Correlation coefficients between the variables Cat and iCa were also analyzed for the two groups studied. Low correlation was found between Cat and $\mathrm{iCa}$ in pre-treatment $(0.39, \mathrm{P}<0.01)$; whereas in the post-treatment there is no correlation between these variables $(0.18, \mathrm{P}>0.01)$.

Only dogs with malignant mammary cancer were include in this study. Among the 119 female dogs initially include in the study, 100 female dogs $(84.1 \%)$ were diagnosed with malignant neoplasms, the most frequent being carcinoma in a mixed tumour (26\%), carcinosarcomas (14\%) and malignant adenomyoepithelioma (13\%). It was observed that in most cases of malignant tumours there was hypercalcemia detected by the serum dosage of ionized calcium, which was not the case for total calcium.

Table 1. Reference values, means and standard deviations, minimum and maximum values measured for total calcium and ionized calcium of animals in pre and post treatment.

\begin{tabular}{lcccc}
\hline Variables & Values of reference** & Pre-treatment $(\mathrm{n}=100)$ & Post-treatment $(\mathrm{n}=94)$ & $P$ \\
\hline \multirow{2}{*}{$\mathrm{Ca} t(\mathrm{mmol} / \mathrm{L})$} & \multirow{2}{*}{$2.25-2.99$} & $\begin{array}{l}2.56 \pm 0.70 \mathrm{a} \\
(2.02-3.79)\end{array}$ & $\begin{array}{l}2.57 \pm 0.90 \mathrm{a} \\
(2.22-3.54)\end{array}$ & 0.9691 \\
\hline \multirow{2}{*}{$i \mathrm{Ca}(\mathrm{mmol} / \mathrm{L})$} & \multirow{2}{*}{$1.00-1.45$} & $\begin{array}{l}1.68 \pm 0.55 \mathrm{a} \\
(1.19-4.11)\end{array}$ & $\begin{array}{l}1.46 \pm 0.31 \mathrm{~b} \\
(1.12-2.88)\end{array}$ & $<0.001$ \\
\hline
\end{tabular}

Cat: total calcium; $i$ Ca: ionized calcium. 
Within the group of 100 female doges with malignant mammary cancer, in 24 animals (24\%) benign tumours were also detected in different affected mammas. Twenty-nine (29\%) animals had tumours in only one mamma and $71(71 \%)$ had more than one affected mamma. The female dogs with malignant neoplasms had an average age of 9.24 \pm 2.89 years old, the youngest being 2 years old and the oldest 15 years old. The most affected mammas by malignant tumour were inguinal $(31 \%)$, followed by caudal abdominals (27\%), cranial abdominals (20\%), caudal thoracic (13\%) and cranial thoracic $(9 \%)$.

Regarding the breeds of female dogs affected by malignant mammary cancer in this study, $41(41 \%)$ animals were of mixed breed, $15(15 \%)$ animals were of the poodle breed and $5(5 \%)$ Rottweiler female dogs, the other animals distributed at low frequency in other breeds.

As for staging, it was found that most animals were in clinical stage III, with 38 animals, and in the other staging there were a similar number of animals. Of the 38 female dogs in stage III (tumours larger than $5 \mathrm{~cm}), 16$ female dogs $(50 \%)$ had large and ulcerated tumours. In the 15 female dogs in stage IV, 10 animals also presented large and ulcerated tumours, in addition to the presence of metastasis in inguinal or axillary lymph nodes. In the 14 female dogs in stage $\mathrm{V}$, the presence of lung metastases was observed in 8 female dogs (57\% of the metastases), in distant lymph nodes in 3 animals (21\%), in bone tissue in two animals (14\%), one in rib and another in the sternum, and one animal (7\%) presented metastasis in the liver.

After the initial clinical approach, clinical staging and complementary exams, the dogs were submitted to the appropriate treatment, unilateral total mastectomy in 60 animals, regional mastectomy in 10 animals, chemotherapy in 3 animals and 4 animals received only palliative care. In 89 (89\%) of female dogs submitted to surgical procedure, ovariohysterectomy was also performed.

The complications observed in the group of 100 female dogs with malignant mammary cancer were the death of 4 animals before the 30-follow-up (4\%), partial dehiscence of the surgical wound suture $(5 \%)$, acute renal failure $(5 \%)$, and one case (1\%) of comorbidity, where the animal was also diagnosed with leukemia. In 43 (43\%) animals there was a change in haematological parameters and in $25(25 \%)$ animals in biochemical parameters. In a previous study with 25 female dogs with mammary tumour, several haematological changes such as anaemia (24\%) and leukocytosis (44\%) and biochemical changes, such as hypocalcaemia (76\%) and hypoalbuminemia (32\%) were detected in a significant number of animals (Duda et al., 2017). For animals in pre and post-treatment, the effect of age on any of the variables was not observed $(\mathrm{P}>0.05)$. According to this, in a previous study with 25 female dogs with mammary tumour, several haematological changes such as anaemia (24\%) and leukocytosis (44\%) and biochemical changes, such as hypocalcaemia (76\%) and hypoalbuminemia (32\%) were detected in a significant number of animals (Duda et al., 2017). As for biochemical tests (ALT, FA, urea and creatinine), it was found that $77 \%$ of female dogs in pre-treatment and $81 \%$ of female dogs in posttreatment showed normal values. Between pre-treatment and post-treatment animals, there was no significant difference $(\mathrm{P}>0.05)$ between presence (YES) or absence (NO) of the serum biochemical changes, and there was also no significant effect $(\mathrm{P}>0.05)$ of the staging over the Cat. For iCa there was a quadratic effect of the staging $(\mathrm{P}=0.026)$, showing that from staging I to II the level of iCa decreased and then those levels increased until stage $\mathrm{V}$ ( Tab 2).

Table 2. Means and standard deviation, for Total Calcium and Ionized Calcium of the animals in pre-treatment in relation to the presence of other biochemical changes and clinical staging.

\begin{tabular}{|c|c|c|c|}
\hline Variables & & $\mathrm{Ca} t(\mathrm{mmol} / \mathrm{L})$ & $i \mathrm{Ca}(\mathrm{mmol} / \mathrm{L})$ \\
\hline \multirow{2}{*}{ Biochemical changes } & Yes $(n=23)$ & $2,58 \pm 1,27$ & $1.88 \pm 0,64$ \\
\hline & No $(n=77)$ & $2,57 \pm 1,01$ & $1.65 \pm 0,53$ \\
\hline \multirow[t]{2}{*}{$\mathrm{P}<$ value } & & $\mathrm{NS}$ & $\mathrm{NS}$ \\
\hline & $\mathrm{I}(\mathrm{n}=15)$ & $2,62 \pm 0,5$ & $1,5 \pm 0,4 \quad a$ \\
\hline \multirow{4}{*}{ 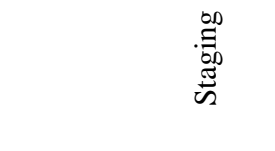 } & II $(n=18)$ & $2,54 \pm 0,7$ & $1,4 \pm 0,2 \quad a$ \\
\hline & III $(n=38)$ & $2,57 \pm 0,5$ & $1,6 \pm 0,4 \quad a$ \\
\hline & IV $(n=15)$ & $2,59 \pm 0,4$ & $1,9 \pm 0,6 \quad b$ \\
\hline & $V(n=14)$ & $2,59 \pm 0,5$ & $2,1 \pm 0,7 \quad b$ \\
\hline $\mathrm{P}<$ value & & NS & $<0,001^{*}$ \\
\hline
\end{tabular}

NS: Not significant, *significant (P < 0.05); R2: Coefficient of determination. Regression equation of iCa as a function of staging: $\mathrm{Y}=1.65-0.187 \mathrm{x}+0.066 \mathrm{x} 2-\mathrm{R} 2=0,27$. 
According to most of the consulted authors, the risk of developing malignant mammary tumours in the canine species can vary. According to most authors of international articles, about 54\% of mammary tumours in the dog are benign (Itoh et al., 2005; Misdorp, 1999; Rutteman \& Kirpensteinjn, 2003; Sorenmo, 2003), with discrepancies when compared to most Brazilian articles, which refer to 68 to $91 \%$ prevalence of malignant tumours (De Nardi et al., 2002; Martins et al., 2002; Oliveira et al., 2003; Zuccari et al., 2001). In the present study, of the 119 female dogs approached with mammary cancer, $100(84.1 \%)$ animals presented malignant neoplasms, that is, a high incidence of malignant tumours when compared to the vast majority of epidemiological studies. Some risk factors can be mentioned, mainly the fact that the female dogs participating in this study were mostly elderly, with a mean age greater than nine years old $(9.24 \pm 2.89)$ and not ovariohysterectomized early. According to a retrospective study of the prevalence of mammary cancer in dogs, where the histopathological evaluation forms of 1,465 dogs with a diagnosis of mammary cancer were evaluated, 390 (26.6\%) were benign neoplasms and 1,075 (73.3\%) were malignant, presenting a close relationship, with the vast majority of malignant tumours, when compared to this study (Oliveira Filho et al., 2010). Regarding the histological pattern, previous studies are often based on the histological classification of mammary tumours suggested by Goldschmidt \& Pena (2011) or the classification by Moulton, from the World Health Organization quoted in Misdorp (1999), reporting a higher frequency of tubule-papillary carcinomas and complex carcinomas. A recently published article on the existence of hypercalcemia in female dogs with mammary cancer, where the histological classification used was the one proposed by Cassali et al. (2014), demonstrated the occurrence of carcinoma in a mixed tumour occupying the second position among the diagnosed tumours in 33\% cases (Raposo-Ferreira et al., 2016). In the present study, the most common histological pattern was carcinoma in mixed tumour $(26 \%)$, according to the classification proposed by Cassali et al. (2014). Carcinoma in mixed tumour has the characteristic of presenting a component of malignant epithelia origin and a component of mesenchymal origin with benign characteristics. There was no statistically significant correlation between increased calcium levels and the histological pattern of neoplasms.

The main result obtained in this study was the finding of the presence of the state of hypercalcemia in $52(52 \%)$ of female dogs with malignant mammary cancer, in the pre-treatment group, when the evaluation was performed by means of serum ionized calcium measurement (iCa), that is, in these animals, the serum ionized calcium dosages was above $1.45 \mathrm{nmol} / \mathrm{L}$. In contrast in only 4 animals (4\%), the total serum calcium (Cat) was increased, demonstrating the importance of using ionized calcium, and not total calcium, to detect hypercalcemia states. In the post-treatment group, this event was also observed. In addition, for iCa there was a quadratic effect of staging $(\mathrm{P}=0.026)$, showing that from staging I to II the level of iCa decreased and then these levels increased to level V. These results demonstrate that even when animals showed changes in biochemical tests or with the increased severity of staging in $\mathrm{iCa}$ has not undergone major changes. In other words, an increase in iCa levels was observed as the clinical stage of the disease was more advanced, especially in stage III. Just as advanced stages of mammary cancer are correlated with a worse prognosis, we could suggest that serum levels of ionized calcium may also be include as a factor related to worse prognosis for patients with malignant mammary cancer. In this study, 39\% of female dogs in clinical stage III were observed (Cassali et al., 2014; Lana et al., 2007). At this stage of the disease, the tumors are larger than $5 \mathrm{~cm}$ in their maximum diameter, but without evidence of migration to lymph nodes or distant metastasis. In the present study, $67 \%$ of the dogs were between stage III and V, stages of the disease where the levels of ionized calcium were significantly higher $(\mathrm{P}<0.05)$.

Malignant hypercalcemia in animals with cancer has been a frequent topic of study in dogs with anal sac carcinomas and lymphoma, mainly related to the production of a peptide similar to parathyroid hormone (Jark et al., 2011; Zandvliet, 2016). In female dog mammary neoplasms, the occurrence of hypercalcemia is frequently reported, but its prevalence and mechanisms are poorly elucidated. A study that included the investigation of serum calcium levels in 20 female dogs with mammary tumours, by measuring total calcium and ionized calcium, detected the presence of the alteration in only two animals that presented malignant neoplasms, but that were later diagnosed with primary hyperparathyroidism, concluding that hypercalcemia related to mammary neoplasms in bitches is rare, but suggesting that it's necessary more studies with a bigger number of animals. In another study, where the occurrence of hypercalcemia through the measurement of total calcium in 51 female dogs with malignant mammary 
tumours, the condition was confirmed in 35\% of the animals studied (Raposo-Ferreira et al., 2016), disagreeing of this study, because when the total calcium dosage was used, only $4 \%$ of the animals presented hypercalcemia. In the present study, hypercalcemia was found in more than half of the group of animals studied (52\%), when the method used was the measurement of ionized calcium. In the study by

Schenck \& Chew (2005) when the total calcium concentration was used to predict the ionized fraction, the disagreement reached 27\%. According to Barber (2001), only the direct determination of ionized calcium concentration formulas. In the present study, hypercalcemia was found in only $4 \%$ of the animals with malignant mammary cancer when the calcium concentration was obtained by means of serum total calcium, against $52 \%$ when the method used was the measurement of ionized calcium, showing a $48 \%$ disagreement.

Malignant hypercalcemia can occur due to different mechanisms in human patients with neoplasia, by osteolysis in primary or metastatic bone neoplasms, by ectopic hyperparathyroidism, by the secretion of the parathyroid hormone (PTHrP) or the production of $1.25(\mathrm{OH}) 2 \mathrm{D}$ for the tumour (Farias, 2005). In the present study, creatinine concentrations were verified, which could correlate the presence of hypercalcemia in patients presenting the condition unrelated to malignancy, but due to changes in renal function, present in eight animals in the pre-treatment group and six in the post-treatment group, taking into account the possibility of occurrence of hypercalcemia as a triggering factor for renal failure (Nelson \& Couto, 2015). However, associations between increased levels of calcium and creatinine were not observed. Increased dosages of AF could also be related to osteoclastic activity when there is bone metastasis, which has not been confirmed. Studies that verify the frequency of occurrence of hypercalcemia as a paraneoplastic syndrome in animals, as well as its mechanisms, should be performed, as the condition is related to a worse prognosis in humans and, in addition, hypercalcemia can be considered as an aggravating factor of morbid conditions, as it can lead to renal, cardiovascular, gastrointestinal and neurological changes (Panciera, 2006).

\section{Conclusion}

Due to the observation of the results obtained in this study, it can be inferred that the female dogs with malignant mammary tumour present malignant hypercalcemia and that the condition may be related to the more advanced stages of the disease, suggesting the realization of new studies that seek to define the mechanisms related to occurrence of hypercalcemia. In addition, only the direct determination of the ionized calcium concentration should be considered, and not its prediction through correction formulas.

\section{References}

Barber, P. (2001). Disorders of calcium homeostasis in small animals. In Practice, 23(5), 262-269. https://doi.org/10.1136/inpract.23.5.262 .

Bartlett, M. S. (1950). Tests of significance in factor analysis. British Journal of Statistical Psychology, 3(2), 77-85. https://doi.org/10.1111/j.2044-8317.1952.tb00117.x.

Bergman, P. J. (2007). Paraneoplastic syndromes. In: Withrow, S.J. \& Vail, D.M. (eds). Small Animal Clinical Oncology. 77-94. St Louis, MO, USA: Saunders Elsevier.

Bergman, P. J. (2013). Paraneoplastics syndromes. In: Withrow, S.J. \& Macewen, E.G. (eds). Small Animal Clinical Oncology. 83-97. Philadelphia: Saunders Elsevier.

Bonczynski, J. (2007). Primary hyperparathyroidism in dogs and cats. Clinical Techniques in Small Animal Practice, 22(2), 70-74. https://doi.org/10.1053/j.ctsap.2007.03.006 .

Cassali, G. D., Lavalle, G. E., Ferreira, E., Estrela-Lima, A., De Nardi, A. B., Ghever, C., Sobral, R. A., Amorim, R. L., Oliveira, L. O., \& Sueiro, F. A. R. (2014). Consensus for the diagnosis, prognosis and treatment of canine mammary tumors-2013. Brazilian Journal of Veterinary Pathology, 7(2), 38-69.

De Nardi, A. B., Rodaski, S., Sousa, R. S., Costa, T. A., Macedo, T. R., Rodigheri, S. M., Rios, A., \& Piekarz, C. H. (2002). Prevalência de neoplasias e modalidades de tratamentos em cães, atendidos no hospital veterinário da Universidade Federal do Paraná. Archives of Veterinary Science, 7(2), 15-26.

Duda, N. C. B., Valle, S. de F., Matheus, J. P., Angeli, N. C., Vieira, L. C., Oliveira, L. O., Sonne, L., \& González, F. H. D. (2017). Paraneoplastic hematological, biochemical, and hemostatic 
abnormalities in female dogs with mammary neoplasms. Pesquisa Veterinária Brasileira, 37(5), 479-484. https://doi.org/410.1292/jvms.67.345.

Farias, M. L. F. (2005). A hipercalcemia nas malignidades: aspectos clínicos, diagnósticos e terapêuticos. Arquivos Brasileiros de Endocrinologia \& Metabologia, 49(5), 816-824. https://doi.org/10.1590/S0004-27302005000500024.

Goldschmidt, M., \& Pena, L. R. (2011). Classification and grading of canine mammary tumors. Veterinary Pathology, 48(1), 117-131. https://doi.org/10.1177/0300985810393258.

Itoh, T., Uchida, K., Ishikawa, K., Kushima, K., Kushima, E., Tamada, H., Moritake, T., Nakao, H., \& Shii, H. (2005). Clinicopathological survey of 101 canine mammary gland tumors: differences between small-breed dogs and others. Journal of Veterinary Medical Science, 67(3), 345-347. https://doi.org/10.1292/jvms.67.345 .

Jain, N. C., \& Jain, A. H. (1993). Essentials of Veterinary Hematology (1st ed.). Wiley-Blackwell.

Jark, P. C., Monteiro, L. N., Grandi, F., Sousa Rocha, N., Lourenco, M. L. G., \& Machado, L. H. A. (2011). Malignant hypercalcemia secondary to anal sac carcinoma in a dog--the importance of indentifyng the paraneoplasic syndromes. Veterinaria e Zootecnia, 18(4), 558-563.

Khosla, S. (2001). The OPG/RANKL/RANK System. Endocrinology, 142(12), 5050-5055.

Lana, S. E., Rutteman, G. R., \& Withrow, S. J. (2007). Tumors of the mammary gland. Small Animal Clinical Oncology, 4, 619-636.

Martins, A. M. C. R. P. F., Tamaso, E., \& Guerra, J. L. (2002). Retrospective review and systematic study of mammary tumors in dogs and characteristics of the extracellular matrix. Brazilian Journal of Veterinary Research and Animal Science, 39(1), 38-42. https://doi.org/10.1590/S141395962002000100007.

Misdorp, W. (1999). Histological classification of the mammary tumors of the dog and the cat. World Health Organization International Histological Classification of Tumors of Domestic Animals Second Series, 7, 1-59.

Nelson, R. W., \& Couto, C. G. (2015). Medicina interna de pequenos animais (Issue 1). Elsevier Editora.

Oliveira Filho, J. C., Kommers, G. D., Masuda, E. K., Marques, B., Fighera, R. A., Irigoyen, L. F., \& Barros, C. S. L. (2010). Retrospective study of 1,647 mammary gland tumors in dogs. Pesquisa Veterinária Brasileira, 30(2), 177-185. https://doi.org/10.1590/S0100-736X2010000200014.

Oliveira, L. O., Oliveira, R. T., Loretti, A. P., Rodrigues, R., \& Driemeier, D. (2003). Aspectos epidemiológicos da neoplasia mamária canina. Acta Scientiae Veterinariae, 31(2), 105-110.

Panciera, D. L. (2006). Fluid therapy in endocrine and metabolic disorders. In D. S. (Ed.), Fluid, electrolyte, and acid-base disorders (pp. 478-489). Elsevier.

Queiroga, F., \& Lopes, C. (2002). Tumores mamários caninos, pesquisa de novos factores de prognóstico. Revista Portuguesa de Ciências Veterinárias, 97(543), 119-127.

Raposo-Ferreira, T. M. M., Varallo, G. R., Calazans, S. G., Jark, P. C., Salvador, R. da C. L., TinucciCosta, M., De Nardi, A. B., Cassali, G. D., \& Laufer-Amorim, R. (2016). Paraneoplastic hypercalcemia secondary to canine mammary tumors. Acta Scientiae Veterinariae, 44(1), 1-7. https://doi.org/10.22456/1679-9216.81107.

Rutteman, G. R., \& Kirpensteinjn, J. (2003). Tumours of the mammary glands. In J. M. Dobson \& B. D. X. Lascelles (Eds.), Manual of canine and feline oncology (pp. 234-242). Gloucester: British Small Animal Veterinary Association.

Schenck, P.A., \& Chew, D. J. (2006). Diseases of the parathyroid gland and calcium metabolism. In R. G. Sherding \& S. J. Birchard (Eds.), Diseases of the parathyroid gland and calcium metabolism (pp. 343-356). Saunders, Elsevier. https://doi.org/10.1016/B0-72-160422-6/50034-6

Schenck, Patricia A, \& Chew, D. J. (2005). Prediction of serum ionized calcium concentration by use of serum total calcium concentration in dogs. American Journal of Veterinary Research, 66(8), $1330-1336$.

Scheneck, P. (2010). Electrolyte disorders: Ca-P and Mg. In S. J. Ettinger \& E. C. Feldman (Eds.), Textbook of veterinary internal medicine (pp. 299-314). Saunders Elsevier: Missouri. 
Shapiro, S. S., \& Wilk, M. B. (1965). An analysis of variance test for normality (complete samples). Biometrika, 52(3/4), 591-611. https://doi.org/10.2307/2333709.

Sorenmo, K. (2003). Canine mammary gland tumors. Veterinary Clinics of North America: Small Animal Practice, 33(3), 573-596.

Wintrobe, M. M. (1974). Clinical hematology. In Academic Medicine. Lea \& Febiger.

Withrow, S. J., Page, R., \& Vail, D. M. (2020). Small animal clinical oncology. Elsevier Health Sciences. https://doi.org/10.1201/9781315381855.

Zandvliet, M. (2016). Canine lymphoma: a review. Veterinary Quarterly, 36(2), 76-104. https://doi.org/10.1080/01652176.2016.1152633.

Zuccari, D., Santana, A. E., \& Rocha, N. S. (2001). Fisiopatologia da neoplasia mamária em cadelasrevisão. Clínica Veterinária, 32(2), 50-54.

Histórico do artigo:

Recebido: 13 de março de 2021

Aprovado: 28 de abril de 2021
Licenciamento: Este artigo é publicado na modalidade Acesso Aberto sob a licença Creative Commons Atribuição 4.0 (CC-BY 4.0), a qual permite uso irrestrito, distribuição, reprodução em qualquer meio, desde que o autor e a fonte sejam devidamente creditados. 